\title{
THE FUTURE OF NEGLIGENCE IN ACCIDENT LAW
}

\section{Fleming James, Jr.*}

$\mathrm{O}$ UTSIDE the field of work injuries, negligence is certainly the dominant concept in accident law today, but the future of its dominance is by no means as clear as it must have seemed at the turn of the century. ${ }^{1}$ The sources of doubt are several. For one thing, social insurance legislation may engulf the whole, or a large part, of the field of accidental bodily injury law. If it does, the legislation might take the form of comprehensive social insurance for disability from any source, as part of the attack on the general problem of poverty. ${ }^{2}$ Or, it might take some form of enterprise liability, as workmen's compensation did, such as that proposed for motor vehicle accidents by Keeton and O'Connell. ${ }^{3}$ There is also the possibility that strict liability may further supplant liability based on fault through the common-law process by judicial decision, as it has already done to some extent in the fields of extrahazardous activities and products liability." The first question I shall explore is the effect each of these possible developments would be likely to have on the concept of negligence. Then I shall try to assess briefly the likelihood that such a development will take place.

Before we examine what each of these developments might do to negligence, it would be just as well to take a look at what negligence is. For present purposes it has two aspects: (1) it is one kind of legal or moral fault which suffices as a basis for tort liability under a system which by and large insists that liability be based on fault; (2) negli-

- Professor of Law, Yale University. B.A., 1925; LL.B., 1928, Yale University.

1 See, e.g., Ives .. South Buffalo Ry., 201 N.Y. 271, 94 N.E. 431 (1911); Ames, Law and Morals, 22 Harv. L. Rev. 97 (1908); Isaacs, Fault and Liability, 31 HARv. L. Rev. 954 (1918). One of the clearest and best accounts of the change of attitude is to be found in Gregory, Trespass to Negligence to Absolute Liability, 37 VA. L. Rev. 359 (1951).

2 Compare Blum \& Kalven, Public law Perspectives on a Private law ProblemAuto Compensation Plans 37-38, 41-44, 83 (1965).

3 Kreton \& O'Connell, Basic Protection for the Traffic Victim 273-483 (1965) [hereinafter cited as KEETON \& O'ConNeLL].

4 See, e.g., Suvada v. White Motor Co., 32 Ill. 2d 612, 210 N.E.2d 182 (1965); Greenman v. Yuba Power Prods., Inc., 59 Cal. 2d 57, 377 P.2d 897, 27 Cal. Rptr. 697 (1963); Henningsen v. Bloomfield Motors, Inc., 32 N.J. 358, 161 A.2d 69 (1960); Prosser, The Fall of the Citadel (Strict Liability to the Consumer), 50 MinN. L. REv. 791 (1966). 
gence is also a rather elaborate set of concepts such as reasonableness of the risk and its foreseeability, the reasonably prudent man and his attributes and characteristics, proximate cause, and so on.

We shall be primarily concerned with the probable vitality of negligence as part of a scheme of liability grounded on fault. But the possibility will be noted that even if fault is displaced in some fields, the concepts which have grown up in negligence-or some of them-may endure as a means of solving some of the problems under the new dispensation, so that negligence may enjoy a kind of vicarious immortality so to speak, though limited in scope.

The first question then is the extent to which fault is likely to remain the basis of compensation for accidental bodily injury if any of the developments described above should take place.

\section{Comprebensive Social Insurance}

To the extent that compensation should be provided by social insurance both the matter of fault and the concepts associated with negligence would be irrelevant. Of course the existence in fact and the duration of injury or disease and consequent disability would be relevant questions, just as they are under present tort law and under workmen's compensation, and these issues might include questions of the causal connection between the injury or disease and the disability. ${ }^{5}$ But if disability itself is the test of compensation, then no other concept associated with the law of negligence would play any part since no question about the source of the injury or disease would be open.

It is by no means clear, however, that tort liability would be completely supplanted by social insurance. The common-law remedy might well be left as an additional or supplemental remedy, to inure to the benefit of the injured person or the state-or in part to each. Thus if insurance benefits should be less than potential tort recoveries, the claimant might be permitted to pursue his common-law remedy for the balance, and the state might (or might not) be allowed to recover the amount of insurance it had paid. ${ }^{6}$

If a broad social insurance scheme kept a place for tort liability, then

5 This assumes that compensation would not be given for inability to work which resulted from the pendency of compensation proceedings rather than the original disease or injury. See Sanchez v. Industrial Comm'n, 96 Ariz. 19, 391 P.2d 579 (1964); Kowalski v. New York, N.H. \& H.R.R., 116 Conn. 229, 164 Atl. 653 (1933).

6 See Fleming, The Collateral Source Rule and Loss Allocation in Tort Law, 54 Calif. L. Rev. 1478, 1514-23 (1966). 
that liability would probably remain grounded on fault, including negligence. Indeed, in that event, the pressure for abolishing or diluting the requirement of fault would probably diminish, and fault itself might be revitalized as a requirement for tort liability, ${ }^{7}$ though it would operate in a narrower sphere.

\section{Enterprise Liability}

Under a scheme of enterprise liability, tort law would also be likely to play a continuing role. In the first place, the statutory remedy need not be exclusive. The Province of Saskatchewan, for instance, has enacted a scheme of strict liability for motor vehicle accidents, which provides compensation only for limited amounts. ${ }^{8}$. The Saskatchewan statute also allows a victim to get further damages by pursuing his common-law tort remedy against anyone whose fault contributed to the injury. ${ }^{\circ}$ And the plan recently proposed by Keeton and O'Connell would make similar provision. ${ }^{10}$ As under broader social insurance, the residual tort liability would be likely to remain grounded on fault, as it is in Saskatchewan.

Even if the newer strict liability should be made an exclusive remedy against some classes of defendants, the chances are that tort remedies against other classes would be left intact. This has been the case with workmen's compensation, which generally excludes other remedies against the employer but allows them against third parties. ${ }^{11}$ And it would probably be the case under an automobile compensation plan which would in all likelihood impose strict liability on ownership or operation of a motor vehicle ${ }^{12}$ and leave unimpaired a victim's commonlaw remedies against parties whose fault contributed to a motor accident in another way, such as by negligent operation of a railroad or improper

TSee Friedmann, Social Insurance and the Principles of Tort Liability, 63 Harv. L. Rev. 241 (1949), suggesting that something of this sort happened in England in the train of wide provision for social insurance.

8 Automobile Accident Insurance Act, 1963, 12 Eliz.. 2, ch. 38 (Sask.), as amended, 13 Eliz. 2, ch. 51 (Sask. 1964). For a good summary of the Saskatchewan plan see KeEton \& O'ConNell 140-48. The Saskatchewan government has also prepared a pamphlet explaining the statute and its operation. See Saskatchewan Government Insurance Office, Saskatchewan's Automobile Accident Instrance Act Fxplained (rev. ed. 1963).

9 See authorities cited note 8 supra.

10 Keeton \& O'Connell 7, 323-26, 441-65.

11 See 2 Larson, Workmen's Compensation 165-97 (1961).

12 See KeEToN \& O'ConNei.I. 370-74. 
maintenance of highways or nearby conditions which jeopardize highway travel.

Beyond this, enterprise liability is not likely to be adopted by legislatures for the whole field of accidental injuries. It presently covers work injuries, and there are some proposals and some pressure for adopting it for motor accidents. Whether legislative schemes of strict enterprise liability will ever reach beyond that is problematical, and if they do, the extension will be piecemeal. In any event, large areas of traditional tort liability will no doubt remain, for at least a long time to come.

\section{Judicial Extensions of Strict Liability}

Under judicial extensions of strict liability the law of negligence is likely to retain a place, though a smaller one than it has now. In the first place, such extensions (like those made by statute) are unlikely to cover all fields of accidental injury. It is highly improbable, for example, that a rule of strict liability will ever govern the field of medical malpractice. Moreover, even when strict liability enters a field, it frequently fails to occupy it completely. In either event, whatever is not taken over by strict liability is left for negligence. Thus some jurisdictions impose strict liability on blasting operations only where they cause injury by casting debris. ${ }^{13}$ Where that is the rule, injuries caused by percussion or concussion from blasting will be redressed only if negligence is shown. ${ }^{14}$ And some courts which have imposed strict liability on the maker of a defective product in favor of an ultimate consumer are not willing to extend the protection of this rule to a bystander hurt by the defect, no matter how foreseeable his injury. ${ }^{15}$ But these courts

13 See, e.g., Coley v. Cohen, 289 N.Y. 365, 45 N.E.2d 913 (1942); Booth v. Rome, W. \& O.T.R.R., 140 N.Y. 267, 35 N.E. 592 (1893); Smith, Liability for Substantial Physical Damage to Land by Blasting-Tbe Rule of the Future (pts. 1-2), 33 Harv. L. Rev. 542, 667 (1920).

Some of the blasting cases are admirably treated in Gregory, stpra note 1, at 388-95. See also Whitman Hotel Corp. v. Elliott \& Watrous Eng'r Co., 137 Conn. 562, 570, 79 A.2d 591, 595 (1951) (citing Gregory's article in discussing and criticizing the New York distinction).

14 See authorities cited note 13 supra.

15 See, e.g., Hahn v. Ford Motor Co., 256 Iowa 27, 126 N.W.2d 350 (1964); Berzon v. Don Allen Motors, Inc., 23 App. Div. 2d 530, 256 N.Y.S.2d 643 (4th Dep't 1965); Restatement (Second), Torts $\$ 402 \mathrm{~A}$, comment $o$ (1965). But see Piercefield v. Remington Arms Co., 375 Mich. 85, 133 N.W.2d 129 (1965); Mitchell v. Miller, 26 Conn. Supp. 142, 214 A.2d 694 (Super. Ct. 1965); Comment, Strict Products Liability and the Bystander, 64 Colum. L. Rev. 916 (1964). 
-or many of them-will let the bystander recover if he can show the maker's negligence. ${ }^{16}$

Judicial extensions of strict liability usually leave negligence available as an alternative basis of recovery, and where they do, it is frequently the practice for plaintiffs to rely on both theories. They often do this in products liability cases today. ${ }^{17}$ This practice may be adopted by plaintiffs to guard against possible limitations upon a new theory whose boundaries are not fully developed. Or it may be used for collateral tactical reasons. As long as the practice persists-for whatever reason -it will keep alive a place for the law of negligence.

Beyond all this, a good many of the concepts which have grown up in negligence law are likely to remain as useful tools for solving some of the problems of strict liability, because they are familiar and also reasonably well adapted to serving ends other than fault which would have relevance under the new dispensation.

This is happening, for instance, in the development towards strict liability in products liability cases. In the ordinary products liability case the negligence issue involves two questions: (1) whether the product is unreasonably dangerous for foreseeable uses and, if it is, (2) whether the maker could liave prevented the unreasonable danger by exercising reasonable care. ${ }^{18}$ Now strict liability theories may make the second inquiry irrelevant, but not the first. No one is held to warrant that his product will cause no injury or even that it is free from danger. What good is a knife that will not cut? Yet if it will, it is just as capable of cutting a finger as a carrot or a stick of wood. Under a warranty theory, or any other strict liability theory whose adoption is likely, the plaintiff will still have to show that he was injnred by some unreasonably dangerous condition or quality of the product. ${ }^{19}$ And in de-

16 See, e.g., Markel v. Spencer, 5 N.Y.2d 958, 157 NE.2d 713, 184 N.Y.S.2d 835 (1959).

17 In all three of the leading cases, see note 4 supra, plaintiffs proceeded on both a negligence and a strict liability theory. The practice apparently persists. See Borowicz v. Chicago Mastic Co., 367 F.2d 751 (7th Cir. 1966); Barnett v. Bailey's Beautician Supply Co., 220 N.E.2d 348 (Ind. App. 1966); Mayfield v. Kulesza, CCH Prod. LinB. Rep. I 5642 (Tenn. App. 1966); Shamrock Fuel \& Oil Sales Co. v. Tunks, 406 S.W.2d 483 (Tex. Civ. App. 1966); Schwarzz v. Macrose Lumber \& Trim Co., 50 Misc. 2d 1055, 272 N.Y.S.2d 227 (Sup. Ct. 1966). The advice of a leading textbook on the subject is that under modern liberal rules of pleading and practice "the plaintiff may and should join all of his potential grounds for recovery in a single action, against all persons potentially liable." 3 Frumer \& Friedman, Products Liabiutty $\$ 46.01$, at 810 (1966).

182 Harper \& James, Torts $\$ \$$ 28.13-.14 (1956).

${ }^{19}$ See Restatement (Second), Torts S 402A (1965) (strict liability without privity 
termining the question of reasonableness, a standard of care and the qualities of the reasonable man must be invoked. A condition is not unreasonably dangerous unless the reasonable man in the maker's shoes, knowing of the condition and the circumstances likely to attend the product's use, would take some precaution to protect consumers and others from the danger. ${ }^{20}$ This calls upon the jury to make one of the same judgments under a rule of strict liability that it must make under a rule of neghigence. It must assess and weigh the liketihood of harm from the condition, taken with the probable seriousness of the harm if it happens, against the cost of taking a precaution which will be likely to avoid the harm.

\section{The Likelibood of These Developments}

The likelihood that comprehensive legislative developments of the kind described above will occur is highly speculative. Beginning with the New Deal there has, of course, been substantial expansion of Social Security and of private insurance schemes and fringe benefits under collective bargaining agreements. All of these innovations have ameliorated somewhat the phight of victims of accidental injury (along with that of victims of many other kinds of misfortune). But so far they pose no serious threat to our present structure of tort liability, although they do pose increasingly serious and vexing problems of cumulative remedies. $^{21}$

As for new statutory systems of enterprise liability, proposals for some kind of automobile accident compensation hold the center of the stage today, with little or no immediate pressure for anything beyond that. Whether auto compensation will be enacted seems to be a question on which one guess is as good as another. The proposals for it made earlier in the century came to littie and lay dormant for a long time;

of seller for "any product in a defective condition unreasonably dangerous to the user or consumer"); id., comments $g-k$; James, The Untowvard Effects of Cigarettes and Drugs: Some Reflections on Enterprise Liability, 54 CALIF. L. REv. 1550 (1966); James, General Products-Sbould Manufacturers Be Liable Witbout Negligence?, 24 TENN. L. Rev. 923, 926-27 (1957); Keeton, Products Liability-Liability Without Fault and the Requirement of a Defect, 41 Texas L. Rev. 855 (1963); Traynor, The Ways and Meanings of Defective Products and Strict Liability, 32 TENN. L. Rev. 363 (1965); Wade, Strict Tort Liability of Manufacturers, 19 Sw. L.J. 5, 13-21 (1965).

20 See authorities cited note 19 supra.

21 See 2 Harper \& James, Torts $\$$ 25.19-.23 (1956); Fleming, supra note 6; James, Social Insurance and Tort Liability: The Problem of Alternative Remedies, 27 N.Y.U.L. REv. 537 (1952). 
but the idea has recently come to have a new lease on life. More people are taking a new look at the shortcomings of the present system. ${ }^{22}$ The principal beneficiaries of that system are becoming increasingly militant in criticizing the proposals. ${ }^{23}$ These things may be signs of a time of change.

Resistance to change, on the other hand, continues strong and powerful, and it may be successful-at least in our time. If that happens, the concept of negligence will continue-at least in name-to dominate accident law. In that event, it is at least a good guess that inroads by judges and juries upon the requirement of fault will continue along pretty much the same lines as tlose they have taken in the recent past-limited and sporadic adoption of out-and-out strict liability in new areas, and a dilution of the substantive and procedural requirements for showing neghigence.

The upshot of all this is that negligence is far from dead or even moribund as a factor in accident law. But its status is likely to undergo some further change. It would probably find a place even under legislative schemes for social insurance, and while its role would be narrower, there might well be a renascence of negligence within it, so that negligence might once again come to have real meaning in terms of fault. If, on the other hand, it should retain its present extensive role in accident law, it is likely to be further diluted until it becomes "negligence in name only," ${ }^{24}$ or "negligence without fault." ${ }^{25}$ As Professor Gregory has said, after summarizing the argnments advanced for enterprise liability:

With this kind of thinking in the air, together with the observable

22 In addition to Keeton \& O'Connell 11-75, see, e.g., Conard, Morgan, Pratt, Voltz \& Bombaugh, Automobile Accident Costs and Payments-Stchies in the EcoNomics of Injury Reparation (1964); Ehrenzweig, "Full Aid" Insurance for the Traffic Victim-A Voluntary Compensation Plan (1954); Green, Traffic Victimis -Tort Law and Insurance (1958); Franklin, Chanin \& Mark, Accidents, Money and the Law: A Study of the Economics of Personal Injury Litigation, 61 Colvm. L. Rev. 1 (1961); James \& Law, Compensation for Auto Accident Victims: A Story of Too Little and Too Late, 26 Conn. B.J. 70 (1952); Morris \& Paul, The Financial lmpact of Automobile Accidents, 110 U. PA. L. Rev. 913 (1962); Rosenberg \& Sovern, Delay and the Dynamics of Petsonal Injury Litigation, 59 ColvM. L. Rev. 1115 (1959).

${ }^{23}$ See, e.g., Knepper, Alimony for Accident Victims, 15 Defense L.J. 513 (1966); President's Column, Automobile Compensation Plans-Vision or Specter, 9 Am. Triat. Law. A. News Letrer No. 10, at 337 (1966).

24 See Leflar, Negligence in Nanne Only, 27 N.Y.U.L. Rev. 564 (1952).

25 See Ehrenzweig, Negligence Without Fault (1951), reprinted in 54 Calif. L. Rev. 1422 (1966). 
growth of liability insurance as an institutional means of risk-bearing and loss shifting, many of our courts, in my opinion, have tended to relax the standards governing negligence and due care in a good deal of what passes for ordinary negligence litigation. ${ }^{26}$ 